\title{
Distribution area of Hyphantria cunea Drury: the analysis of Ukrainian and world data
}

\author{
Yu. O. Nakonechna https://orcid.org/0000-0003-3381-1347 \\ S. V. Stankevych https://orcid.org/0000-0002-8300-2591 \\ I. V. Zabrodina https://orcid.org/0000-0001-8122-9250 \\ I. P. Lezhenina https://orcid.org/0000-0001-6510-4781 \\ M. O. Filatov https://orcid.org/0000-0003-2357-1853 \\ D.D. Yushchuk https://orcid.org/0000-0003-1717-3605 \\ N. V. Lutytska https://orcid.org/0000-0002-6438-0888 \\ O. A. Molchanova https://orcid.org/0000-0001-5656-7450 \\ V. O. Melenti https://orcid.org/0000-0003-4196-5274 \\ V. M. Poliakh https://orcid.org/0000-0002-7479-1912 \\ S. M. Buhaiov https://orcid.org/0000-0001-6655-020 \\ Yu. M. Belay https://orcid.org/0000-0003-1446-8168 \\ V. I. Martynenko https://orcid.org/0000-0001-6730-9502 \\ L. V. Zhukova https://orcid.org/0000-0003-1549-8019 \\ I.M. Buzina https://orcid.org/0000-0002-0885-0558 \\ D.D. Khainus https://orcid.org/0000-0001-6097-1464
}

\author{
V.V. Dokuchaev Kharkov National Agrarian University \\ Dokuchaevske Village, Kharkiv region, 62483, Ukraine \\ Corresponding author E-mail: sergejstankevich1986@gmail.com. Tel.: +38-050-4000-985.
}

Received: 27.09.2019. Accepted: 27.10.2019

\begin{abstract}
Hyphantria cunea Drury is a polyphagous quarantine pest, which is not evolutionarily tied to the territory of Ukraine. We have analyzed data from literary sources on the geographical spreading of Hyphantria cunea Drury, indicated the current area of the pest and noticed factors that influence the acclimatization of a pest. The motherland of Hyphantria cunea Drury is North America; in 1770, an entomologist Druri first described this species. The first indications of the harmfulness of Hyphantria cunea Drury are noted in the USA in 1899 and on the European continent Hyphantria cunea Drury was found near the city of Budapest (Hungary) on the island of Chepel in August 1940. By 1948, the pest had spread throughout Hungary and began to occupy the tree plantations of neighbouring countries, such as the Czech Republic, Slovakia, Yugoslavia, Romania, and Austria. At present, the pest is widespread in Europe, Asia, and North America. In Europe Hyphantria cunea Drury was found in countries such as: Austria, Azerbaijan, Bulgaria, Greece, Georgia, Italy, Moldova, Germany, Russia, Romania, Serbia, Slovakia, Slovenia, Turkey, Hungary, Ukraine, France, Croatia, and the Czech Republic. In 1945 Hyphantria cunea Drury was found in Japan, in the parks of Tokyo. In 1979 in China in Liaoning Province and in Southern Korea it was first described in 1958. In 2003, small foci of caterpillars of Hyphantria cunea Drury were found in Wellington (New Zealand). In Russia, the first foci of mass reproduction of Hyphantria cunea Drury were discovered in the forests of Krasnodar Krai in Krasnodar and Abinsk forest enterprises in 1976 on an area of 270 hectares. In Ukraine, the first foci of Hyphantria cunea Drury were found in Transcarpathia in 1952, in June, virtually all over the lowlands of the region. In the Northeastern part of the Forest-Steppe of Ukraine, in Sumy region in particular, Hyphantria cunea Drury was first registered in 2010. In Kharkiv region Hyphantria cunea Drury was discovered at the beginning of 80 s of XX century. This article highlights the peculiarities of spreading of Hyphantria cunea Drury and its harmfulness. We have also established the ways of penetration and the current area of pest spreading in Ukraine and in the world. We have carried out the analysis of spreading data of the regulated pest in the territory of Ukraine and in the world, including in the territory of Kharkiv region and the factors, which influence the pest acclimatization have been noted.
\end{abstract}




\section{Introduction}

Losses caused to agriculture by pests, weeds and plants diseases are extremely high. According to the Food and Agriculture Organization (FAO) of the United Nations, the world's losses because of them every year are around 20-25\% of the world's potential food crop yield (Yemec, 2014).

During the period from 1920 to 2000 on the territory of the former USSR about 100 alien species of phytophagous insects acclimatized. A significant part of these species refers to a harmful category, and 8 - to dangerous quarantine species. In other regions of the world the number of acclimatized alien insect species is significantly higher (Severin, 1921; Izhevskij, 1990, 2002). Biological invasions of different organisms have caused enormous changes in ecosystems (Kuznecov, 2010). Scientists in their studies note that one of these species is Hyphantria cunea Drury - polyphagous quarantine pest, one of the most common in Ukraine. Numerous researches on the biology and ecology of Hyphantria cunea Drury show that since penetration it has taken an important place not so much in anthropogenic as in natural biocenosis. This is confirmed by a significant number of predators, parasitoids and diseases that limit its number in Ukraine (Sikura, 2000; Movchan, 2002; Trigob'yuk, 2005; Stankevych, 2015; Lezhenina, 2016).

The population of Hyphantria cunea Drury is characterized by high viability due to its polyphagia (Boguleunu, Nica \& Petresen, 1976; Greenblatt, Calvert \& Barbosa, 1978; Hidaka, 1979; Yemec, 2014).

Mezentseva L.L. (1989) states that Hyphantria cunea Drury damages about 230 plant species, including grapes. But according to other scientists' data (Davidenko, 2008; Zapolovskij, 2013; Chumak 2013; Tokar, 2014; Bondarenko, 2015), the caterpillars of Hyphantria cunea Drury can feed on 636 species of fruit, ornamental, forest and other crops, among which phytophagous damages 200 species in North America, 234 in Europe, and more than 300 plant species in Asia (Hukuhara \& Hashimoto, 1966; Hirai, 1977; Jaenike \& Selander, 1980; Jarfas, 1986).

At present, in Ukraine the nutrition of Hyphantria cunea Drury is recorded on more than 250 species of fruit and ornamental breeds, and therefore it is characterized as extremely aggressive and dangerous harmful organism which causes great damage to perennial plantations. This pest causes the greatest damage to ash-leaved maple, mulberry tree, apple tree, pear tree, plum, quince-tree, bird-cherry, walnut (Morris \& Futtion, 1970; Morris, 1972; Jarfas. \& Viola, 1986; Morris, 1987; Timchenko, 1988; Morgun, 2001). One of the main signs that diagnoses Hyphantria cunea Drury in the plantations is the presence of spider's web nests in the trees. Caterpillars of 1-2 ages form nests of several leaves, which are densely enlaced with spider's web. At the end of 5th age of caterpillars the nest can reach the size of 1.0-1.5 m. Coarse leaves eating is typical during the development of caterpillars of older ages. According to scientists' studies damage to trees by Hyphantria cunea Drury leads to defoliation of plantations, namely the violation of metabolic processes in the plants and their weakening. As a result, yield, protective, ornamental and aesthetic function of plantations is reduced; conditions for the fauna existence deteriorate. Individual plants become weaker and with repeated damage can die. Fruit and berry crops decrease the yield or don't bear fruit at all, not only in the year of severe damage but also the next year. Trophic relations play one of the main roles in the development of pests. Depending on the state of population and meteorological conditions of the vegetative period the caterpillars of Hyphantria cunea Drury, like other polyphagous, prefer certain species and cultivars of plants which they feed on. The presence of sufficient forage base determines the duration of development, viability, mass of caterpillars and pupae, as well as the fertility of butterflies ((Nady, Rcichart \& Ubrizsy, 1953; Nordin, Rennels \& Maddox, 1972; Shestopalov, 2012, Stankevych, 2017).

\section{Methods}

The purpose of the article is to analyze the data of literature sources as to geographical spreading of Hyphantria cunea Drury, to indicate the current area of the harmful organism and note the factors, which influence pest acclimatization.

The research data is based on literature sources and analysis of the dynamics of the quarantine organism spreading since its penetration into Europe. Our research was carried out during 2014-2019 in Kharkiv region (neighborhood of the village Mala Rogan, $49^{\circ} 56^{\prime} 19^{\prime \prime} \mathrm{N}, 36^{\circ} 29^{\prime} 26^{\prime \prime} \mathrm{E}$ ) according to generally accepted methods during the vegetative period - we recorded the number of trees with caterpillars' nests, estimated the degree of trees settlement, counted the total area of foci of the infection, and identified the forage plants.

\section{Results and Discussion}

According to research data, the motherland of Hyphantria cunea Drury is North America (Ignatyuk, 2013; Nakonechna, 2019). In 1770 this species was described by an entomologist Druri. The primary area of Hyphantria cunea Drury is located on the North American continent from the Pacific to the Atlantic coast, and in the latitudinal direction - from the southern border of coniferous forests of Canada (extending between 54 and 58 north latitude) to the state border of the USA and Mexico. The first indications of the harmfulness of Hyphantria cunea Drury are noted in the USA in 1899 (Howard, 1899). Outbreaks of mass reproduction were noted in 1921 p. (Severin, 1921) and 1969 (Warren, 1970).

On the European continent the first specimens of Hyphantria cunea Drury were found near the city of Budapest (Hungary) on the island of Chepel in August 1940. There is evidence to think that the pest was brought to the island with some cargo. And in 1945 in Japan, where it quickly began to cause significant damage to fruit crops, mulberry tree, ornamental plants and field protective plantations and was included in the list of quarantine objects (Ito \& Miyashita, 1968, Yasyukevich, 2013). According to other data (Hirai,1969), for the first time the pest was found in Japan in 1947 in the parks of Tokyo.

In 1979, the pest was discovered in China in Liaoning Province (State Environmental Protection Administration of Chine, 2001). In Southern Korea Hyphantria cunea Drury was first described in 1958 (Kind, 1991).

By 1948, the pest had spread throughout Hungary and began to occupy the tree plantations of neighboring countries, such as the Czech Republic, Slovakia, Yugoslavia, Romania and Austria. At present, the pest is widespread in Europe, Asia and North America. In Europe Hyphantria cunea Drury was found in countries such as: Austria, Azerbaijan, Bulgaria, Greece, Georgia, Italy, Moldova, Germany, Russia, Romania, Serbia, Slovakia, Slovenia, Turkey, Hungary, Ukraine, France, Croatia, the Czech Republic (Figure 1, see Movchan, 2002).

In Bulgaria in 1962 one spider's web nests with caterpillars of Hyphantria cunea Drury was discovered for the first time and in 1963 there were 880 of them (Boehrn, 1976). In France Hyphantria cunea Drury was first found in 1977 (Jarfac, 1986). In Absheron 
Region of Azerbaijan Hyphantria cunea Drury was found in 1991-1992 (Gaziyev, 1999). At the beginning of the XXI century Hyphantria cunea Drury penetrated from the territory of Azerbaijan into Iran and began to spread in the northern provinces of the country (Gninenko, 2005).

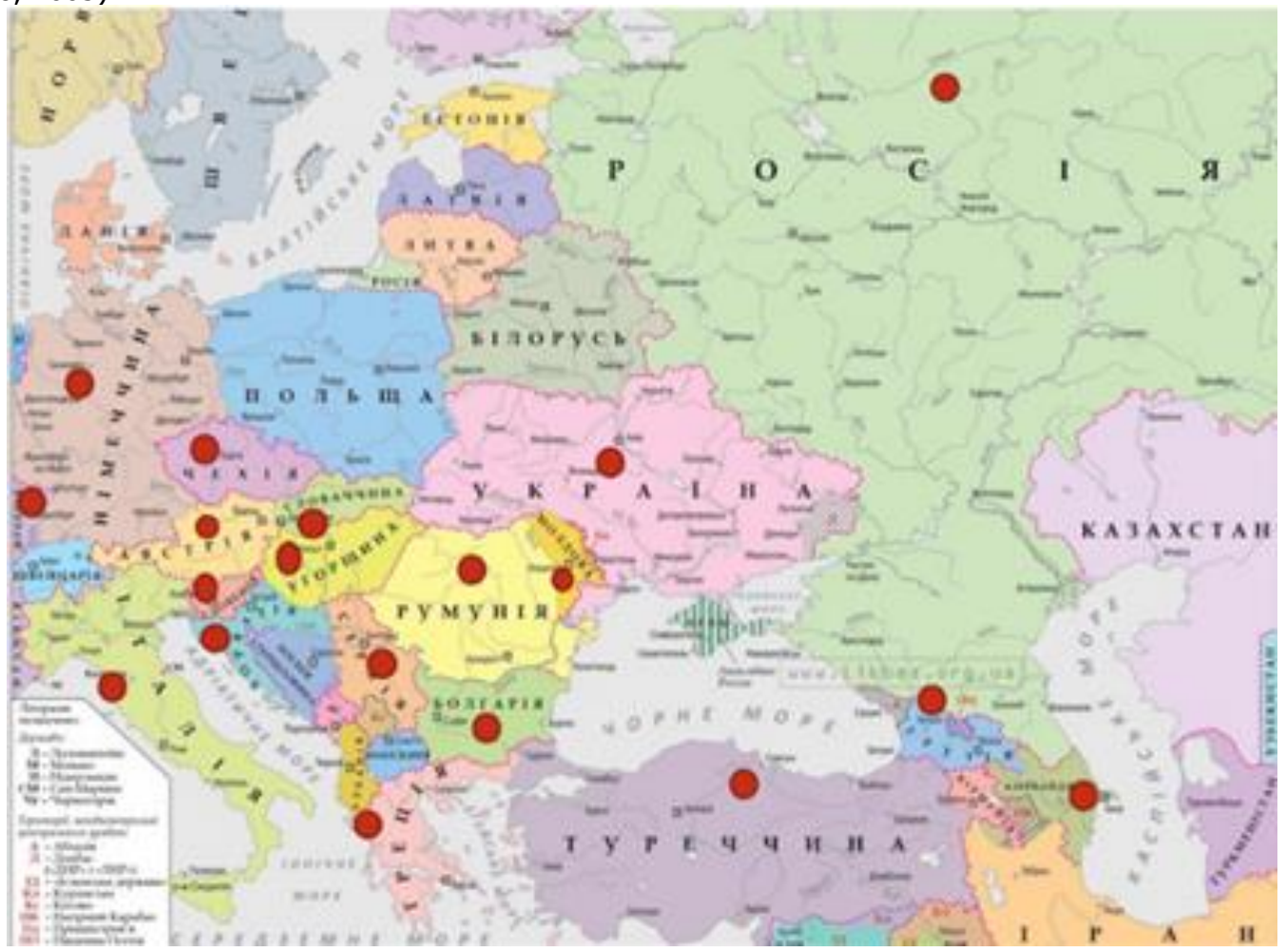

Figure 1. Distribution area of Hyphantria cunea Drury in Europe.

The first signals of damage to tree and shrub vegetation by caterpillars of the pest came from Northern Kyrgyzstan in 2005. During the route surveys, the foci of Hyphantria cunea Drury were found on the territory of Issyk-Altin and Alamedyn districts of Chui region including in 22 inhabited settlements along the by-pass highway and "Bishkek-Torugart" highway and in green plantation of the cities of Kant and Bishkek (Morkovkina, 2006). In 2003, small foci of caterpillars of Hyphantria cunea Drury were found in Wellington (New Zealand) (Kean, 2007).

In Russia, the first foci of mass reproduction of Hyphantria cunea Drury were found in the forests of Krasnodar Krai in Krasnodar and Abinsk forest enterprises in 1976 on an area of 270 hectares. Gradually the foci spread in the forests of Adygea. The total area of foci of Hyphantria cunea Drury in the forests of Kuban in 1982 was 794 hectares. During the next years, the area of foci was reduced and in 1986, the area was 531 hectares. Since 1987, there wasn't any information on foci of mass reproduction of Hyphantria cunea Drury in the forests of Krasnodar Krai and Adygea in reporting data of forest management until 1995, when the foci were found again on an area of 100 hectares (Gninenko, 2005). In Ukraine the first foci of Hyphantria cunea Drury were found in Transcarpathia in 1952, in June, virtually all over the lowlands of the region (Figure 2, see Shumov, 2018).

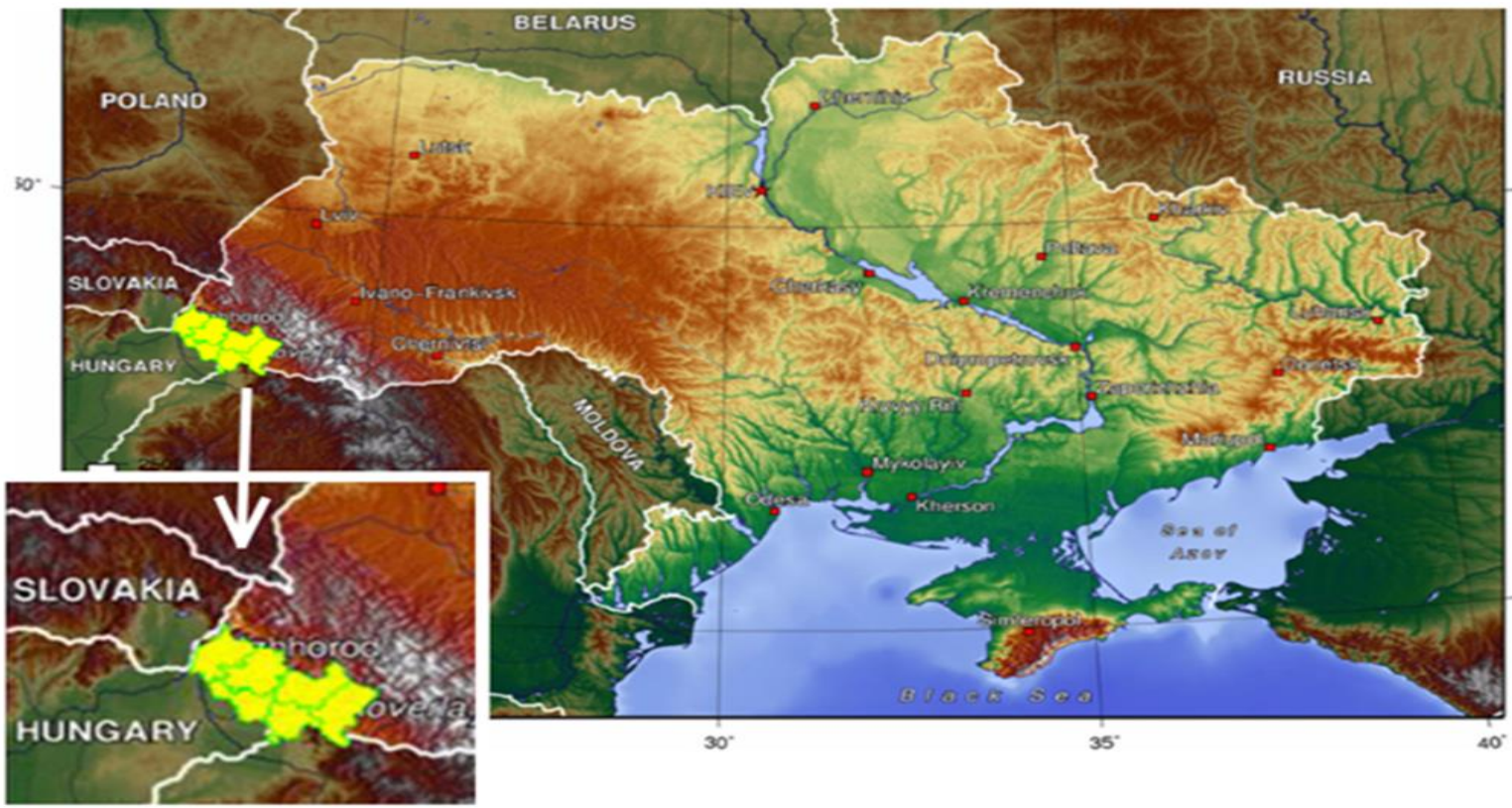

Figure 2. Areas of Transcarpathia Region, where Hyphantria cunea Drury was recorded for the first time (1952) (the fragment below is increased). Shumov, 2018. 
Over the next two years, the pest moved northward by $10-15 \mathrm{~km}$ and in the valleys of the Latorica, Borzhava and Tisza rivers individual foci were found in the depth of the foothills. The further spreading of Hyphantria cunea Drury, as I.A. Churayev believed (1962), was suspended as a result of extraordinary measures, taken to fight against them. He believed (Churayev, 1958), that through the flight of Hyphantria cunea Drury the penetration of a pest from Transcarpathia is possible into Lviv, Ternopil and IvanoFrankivsk regions. Although I.A. Churayev suggested that the Carpathians are a temporary obstacle on the way of natural settling of Hyphantria cunea Drury from Transcarpathia in the eastern direction.

M.P. Umnov (1955) and K.K. Fasulati (1957) pointed out the importance of the Carpathian massif as an obstacle to the settling of the harmful organism. At the same time, M.P. Umnov (1955) wrote that Hyphantria cunea Drury is exceptionally plastic species to the climatic conditions and that the zone of its possible acclimatization should be considered almost the entire European part of the USSR (except northern regions) and all the republics of Central Asia and Transcaucasia. K.K. Fasulati (1957) considered this thought as incapable, pointing out that the area will be determined not only by temperature and humidity, but by the whole complex of landscape and ecological conditions. Concerning Transcarpathia, in 1957 K.K. Fasulati (1957) wrote that Hyphantria cunea Drury in Transcarpathia occupied everything that it could occupy - all natural biotopes in the plain part. Researchers A.Y. Sikura (1962) and V.Yu. Dulo (1978) believed that in the foothills climatic conditions play only an indirect role in restriction of number of Hyphantria cunea Drury, and the main role belongs to entomophages of the butterfly (Sikura, 2000).

According to V.A. Bykovsky's data (1998) Hyphantria cunea Drury refers to species in which the outbreak of mass reproduction is replaced by many years depression. This is inherent and to some other Lepidoptera. The reasons for this phenomenon have not been determined but probably a number of factors causes them. According to the scientist's observations if the number of Hyphantria cunea Drury rises in one part of area, in another it can reduce. Outbreaks and depressions of number are described for Transcarpathia and Odessa regions.

As of 2013, Hyphantria cunea Drury was found in 20 regions of Ukraine on an area of 50098.627 hectares, which is 1389.8 hectares less compared to 2012. In 2014 the area of pest settling increased by 21.9 as a result of revealing of new and expansion of old pest foci in Zhytomyr, Ivano-Frankivsk and Sumy regions. For the first time, quarantine regime for Hyphantria cunea Drury was introduced in Zhytomyr district of Zhytomyr region on an area of 20 hectares and in Tlumatsky district of Ivano-Frankivsk region on an area of 0.7 hectares. At the same time, because of the absence of cases of pest detection during the observations of many years, quarantine regime was cancelled in 7 districts of Kherson region on the total area of 1411.7 hectares (Bazikina, 2015). In the North-Eastern part of the Forest-Steppe of Ukraine, in Sumy region in particular, Hyphantria cunea Drury was first registered in 2010 (Yemec, 2014). In Zhytomyr region the pest was first discovered in Ruzhyn district in 2011, quarantine regime in the urbantype settlement of Ruzhyn was introduced on an area of 1.72 hectares (Ignatyuk, 2013). According to the State service of Ukraine on Food Safety and Consumer Protection as of 01.01.2019 Hyphantria cunea Drury was found in 20 regions. The total area of spreading at the end of 2018 decreased by 12959 hectares and makes 36417 hectares.

Combining the maps of Eco regions of Ukraine and the administrative districts where Hyphantria cunea Drury was recorded, since 1952 to the present, a map of pest spreading in the steppe and forest-steppe zones of Ukraine has been obtained, which according to the basic provisions corresponds to biological characteristics of the harmful organism (Shumov, 2018) (Figure 3).

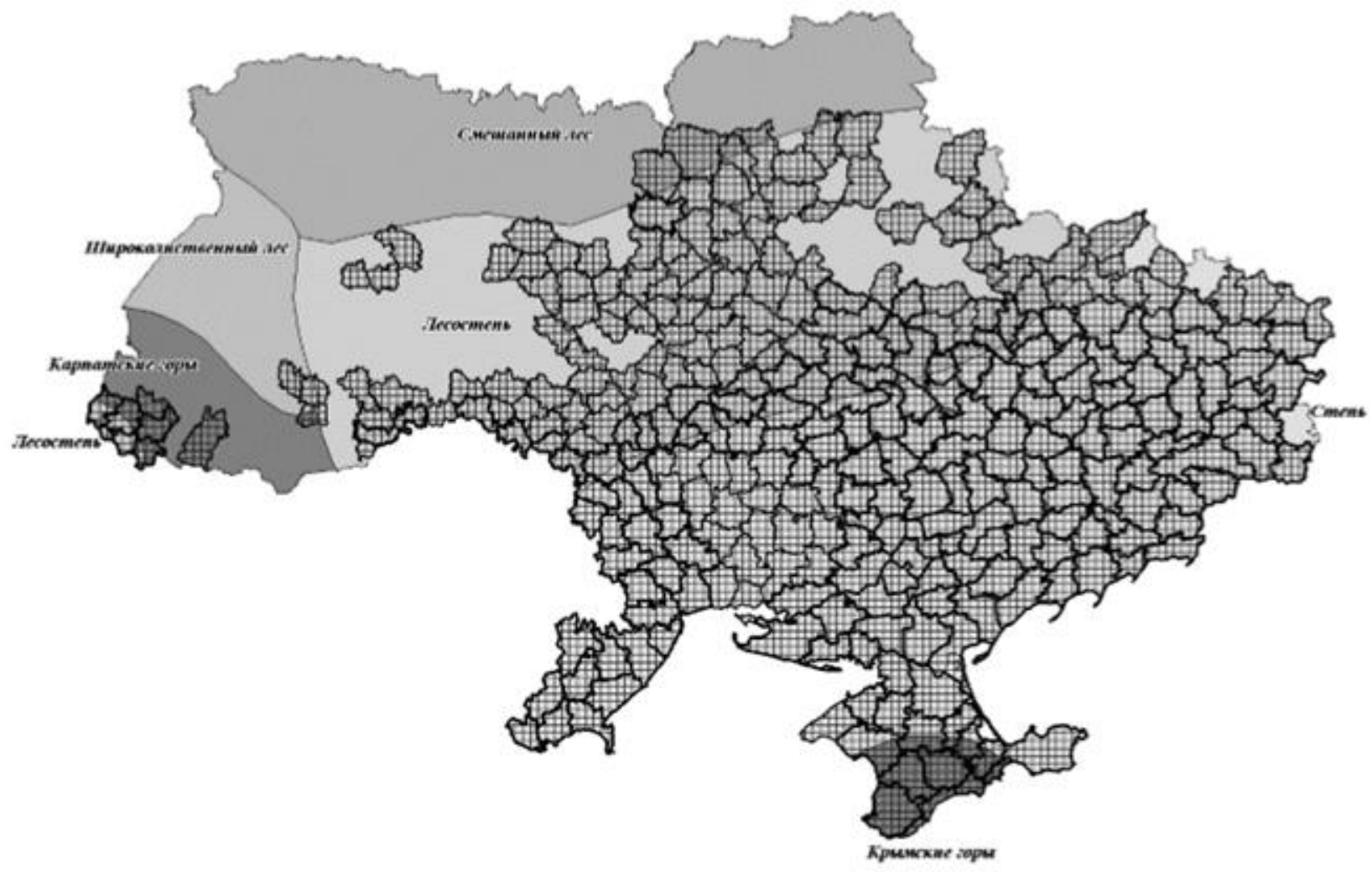

Figure 3. The administrative districts of Ukraine where Hyphantria cunea Drury has been discovered since 1952 vs Eco regions of Ukraine (Shumov, 2018)

In Kharkiv region Hyphantria cunea Drury was discovered in the early $80^{\text {s }}$ of XXI century (Stankevych, 2016, 2017, 2018; Stankevych, 2017). According to the data of the State service of Ukraine on Food Safety and Consumer Protection in 2017 the pest was registered in 24 districts of Kharkiv region on the total area of 2429.5 hectares. A significant part of the inhabited territory falls on homestead lands $-57.4 \%$, on the territory of farms of all forms of ownership- $19.2 \%$ and on other lands $-24.4 \%$ (Figure 4 ). 


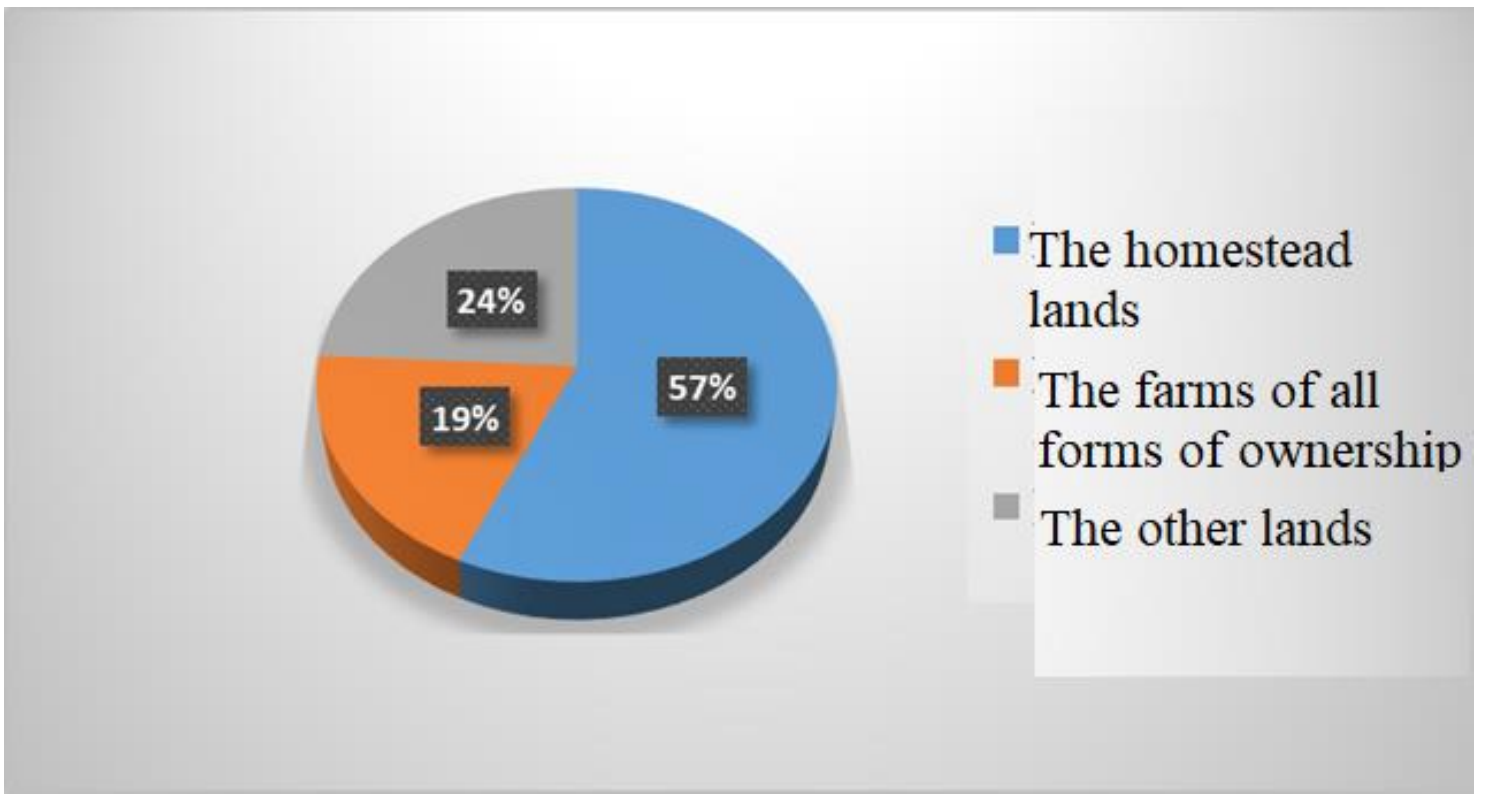

Figure 4. Habitat distribution of Hyphantria cunea Drury in Kharkiv region, 2017.

The most common pest was in Lozova ( 810 hectares), Blyzniuky (518.5 hectares) and Barvinkove (249.9 hectares) districts, the least - in Izium district - 0.3 hectares. According to the data of control surveys in 2017, a new focus of Hyphantria cunea Drury was discovered on the territory of Bohodukhiv district with the total area of 18 hectares.

In 2014 we discovered a new focus on the territory of Kharkiv district where our research was being conducted during 2014-

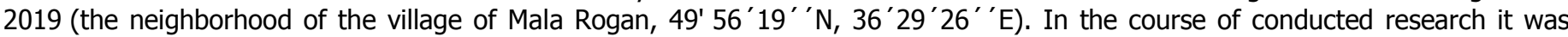
determined that in 2014 on the territory of Village Council of Mala Rogan Hyphantria cunea Drury fed only on ash-leaved maple, which grows along the road that connects the village of Mala Rogan and the highway Kharkiv-Rostov. The length of this section of the road is $1.7 \mathrm{~km}$ (Figure 5).

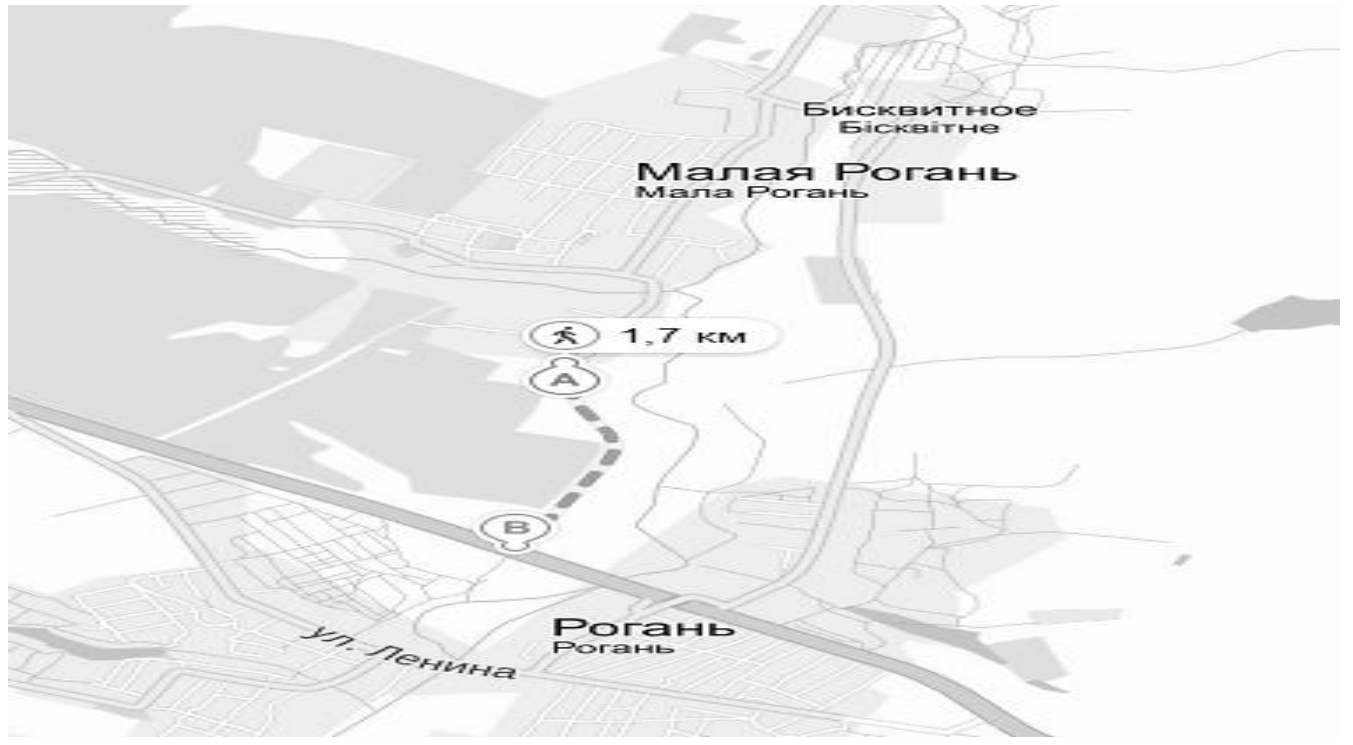

Figure 5. The concentration of Hyphantria cunea Drury in the territory of Village Council (Mala Rogan, 2014-20198).

In 2014 during the accountings, 11 nests of the pests were counted, in 2015-83 nests and 496 nests in 2016. In 2016, the caterpillars developed not only in ash-leaved maple, but also in wild pear tree and sloe. Besides, in 2016 the first nest was noted on the territory of Rogan Village Council, which borders Village Council of Mala Rogan of Kharkiv district. In the spring of 2017 ashleaved maple along the road that connects the village of Mala Rogan and the highway Kharkiv-Rostov, was cut down by almost $50 \%$. However, in the course of accountings it turned out that it did not have a negative impact on the number of the pest. Hyphantria cunea Drury began settling in maple trees that grow in an abandoned garden of chokeberry that, borders the highway. At the same time, not a single nest was noted in chokeberry. In total 681 of spider's web nests of the pest were counted in the course of accountings in 2017. It is also interesting that not a single nest was found on annual shoots of ash-leaved maple that grow on the place of cutting. All nests were concentered on shoots at the age of two years and older. In 2018, the focus continued to grow. During the route surveys 762 spider's web were discovered. In 2018, the pest along with the forage plant (ash-leaved maple) spread into adjacent to the road garden of chokeberry, which is almost completely littered with the plants of ash-leaved maple. The nutrition of caterpillars of Hyphantria cunea Drury was not revealed on chokeberry itself. In addition, the first spider's webs were noted in ash-leaved maple on Lermontov Street (Mala Rogan) at a distance of $1500 \mathrm{~km}$ from the main location, which allows expecting for further growth of the pest number and the expansion of its focus. As we can see, over the five years, the number of pest's nests has increased almost 70 times. 
Our research shows that Hyphantria cunea Drury has a high reproduction coefficient, but it remains economically insignificant pest in Kharkiv district, because it is focused only in ash-leaved maple. Nevertheless, as the experience of other countries in which this species has spread testifies it should be systematically monitored and, if necessary, localize the focus and apply extermination measures.

\section{Conclusion}

The penetration of the pest into new territories happens with the help of airflows, as well as inobservance of quarantine and phytosanitary measures. The average speed of spreading of Hyphantria cunea Drury on the territory of Ukraine is 30-40 km per year. Thus, despite the quarantine and extermination measures, which to some degree inhibit the activity of Hyphantria cunea Drury spreading, its expansion into new suitable for existence territories is continuing. The world's area of Hyphantria cunea Drury has not stabilized up to now and continues to broaden, mainly due to meridional settling. The data of our research shows that of Hyphantria cunea Drury has a high reproduction coefficient, but it remains economically insignificant pest in Kharkiv district, because it is focused only on ash-leaved maple. However, as the experience of other countries in which this species has spread testifies it should be systematically monitored and, if necessary, localize the focus and apply extermination measures.

\section{References}

Bailey R.G. (1989). Explanatory supplement to Ecoregions Map of the Continents. Environmental Conservation, 16 (4), 307-309.

Beleckij E. N. \& Stankevich S. V. (2018). Policiklichnost', sinhronnost' i nelinejnost' populjacionnoj dinamiki nasekomyh i problemy prognozirovanija, Vienna, Premier Publishing s.r.o. Vienna (in Russian).

Beleckij E. N., Stankevich S. V. \& Nemerickaja L. V. (2017). Sovremennye predstavlenija o dinamike populjacij nasekomyh: proshloe, nastojashhee, budushhee. Sinergeticheskij podhod. Vesti HNAU im. V. V. Dokuchaeva. Series Fitopatologija i jentomologija, 1-2, 22-33. (in Russian).

Boehm H.A. (1976). 25 years of Hyphantria cunea and Ceratitus Capitata in Austria. Gn:Land- und Forstwirtsehaftliche Forschung in Oesterreich. Band VII. Vienna, Austria, 81-88

Boguleunu G., Nica F. \& Petresen E. (1976). Influence of the trophic factor on the development of hairy caterpillars of the fall webworn (Hyphantria cimea Drury). Analete Institutui de Cercetari pentru Protectia Plan-telor, 11, 167-175.

Bondarenko V.V. (2015). Prognoz fitosanitranogo stanu agrocenoziv, rozpovsyudzhennya karantinnih organizmiv na teritoriyi Harkivskoyi oblasti ta rekomendaciyi shodo zahistu i karantinu roslin u 2015 roci. Harkiv, Planeta-print (in Ukrainian).

Bykovskij V.A. (1998). Osobenosti razvitiya amerikanskoj beloj babochki. Zashita i karantin rastenij, 8, 35. (in Russian).

Bykovskij V.A. (1999).Osobennosti razvitiya amerikanskoj beloj babochke na Severnom Kavkaze, i faktory, reguliruyushie eyo chislennost. Thesis of Doctoral Dissertation. Moscow (in Russian).

Chumak P.Ya. (2013). Ekologichno bezpechnij zahist roslin vid invazijnih shkidlivih organizmiv v umovah mista. Naukovij visnik NLTU Ukrayini, 23 (17), 79-85. (in Ukrainian).

Churaev I.A. (1962). Amerikanskaya belaya babochka. Moscow (in Russian).

Churaev I.V. (1958). K voprosu o kormovoj specializacii amerikanskoj beloj babochki (Hyphantria cunea Druru.). Trudy VIZR, 11, 85-101. (in Russian).

Fasulati O.O. (1957). O haraktere raspredeleniya amerikanskoj beloj babochki (Hyphantria cunea Druru) v Zakarpatskoj oblasti. Proceed. Uzhgorod University. Series Biological, 72-74. (in Russian).

Gninenko Yu.I. \& Lyazgunov M.E. (2005). Amerikanskaya belaya babochka-dinamika chislennosti v lesah Rossii. Byulleten №5 Postoyannoj Komissii po biologicheskoj zashite lesa Biologicheskaya zashita lesa: problemy i zadachi razvitiya. MOBB VPRS, Pushkino, 32-34. (in Russian).

Golovan L. V., Klymenko I. V. \& Stankevych S. V. (2019). The inheritance of economically valuable features in the intraspecific hybridization of bean (Phaseolus L). Ukrainian Journal of Ecology, 9 (2), 156-169.

Greenblatt J.A., Calvert W.H. \& Barbosa R. (1978). Garval feeding preferences and inducibi-lity in the fall Webwora, Hyphantrea cunea. Ann Entomol Soc. America, 71, 4, 605-606.

Hidaka T. (1979). Biology of Hyphantria cunea (Drury) (Gepidoptera, Arctiidae) in Japan. XIV Mating Behavior Appl Entomol Gool, 7, 3, $116-132$.

Hirai J. (1969). Biology of Hyphantria cunea in Japan. VIII Experimental Studies of the timing mechanism of adult exclosion. Appl. Entomol. Gool., 1, 42-50.

Hirai J. (1977). Biology of Hyphantria cunea in Japan. XIII Temperature drop as a time cue for adult exlosion. Appl. Ent. Gool, 7, 52-60.

Howard J.O. (1899). Three insect enemies of shade trees. By Z.O. Howard Washington. You print off, 30.

Hukuhara T. \& Hashimoto J. (1966). Virus diseases of Hyphantria cunea. Jan J. Appl Gool, 10, 3.

Ignatyuk A.I., Rudenko Yu.F. \& Plotnicka N.M. (2013). Viyavlinnya, lokalizaciya i likvidaciya amerikanskogo bilogo metelika v Zhitomirskij oblasti. Visnik ZhNAEU, 1, 100-108. (in Ukrainian).

Izhevskij S.S. (1999). Introdukciya i primenenie entomofaga. Moscow, Agropromizdat (in Russian).

Izhevskij S.S. (2002). Invaziya: neizbezhnost i kontrol. Moscow, Agropromizdat (in Russian).

Jaenike J. \& Selander R.R. (1980). On the queston of host races in the full Webworm, Hyphantria cunea. Entomol exper. Appl, 27, 1, 31-37.

Jarfas J. \& Viola M. (1986). Activity and nutrition of Hyphantria cunea. Kerteszeti Edyetem Kozlemeyei, 49, $173-182$.

Jarfas J. (1986). Activity and nutrition of Hyphantria cunea, Keerteszeti Esvetem Kozlemenyei, 50, 251-258.

Jarfas J. N. (1986). Activity and nutrition of Hyphantria cunea II, Keerteszeti Esvetem Kozlemenyei, 50, $251-258$.

Kean J.M. \& Kumarashinge L.B. (2007). Predicting the seasonal phenology of fall webworm (Hyphantria cuned) in New Zealand. New Zealand plant protection, 60, 279-285.

Kuznecov V.N. (2010). Invaziya nasekomyh v nazemnyh ekosistemah dalnego vostoka Rossii. Biologicheskie invazii, 1, 12-17. (in Russian). Lezhenina I.P., Stankevich S.V. \& Zabrodina I.V. (2016). Amerikanskij bilij metelik - Hyphantria cunea (Druru,1773) v Harkivskij oblasti. Harkivskij nacionalnij agrarnij universitet im. V.V.Dokuchayeva. Visnik HNAU. Series Fitopatologiya ta entomologiya, 1, 47-51. (in Ukrainian).

Mezenceva L.L. (1989). Amerikanskaya belaya babochka na vinogradnoj loze. Zashita rastenij, 2, 40. (in Russian).

Morgun R.Yu. (2001). Kormovi roslini i rozvitok ta zhittyediyalnist amerikanskogo bilogo metelika. Zahist roslin, 2, 20. (in Ukrainian).

Morkovkina A.B. \& Milko D.A. (2006). V Kirgizii obnaruzhena amerikanskaya belaya babochka. Zashita i karantin rastenij, 9, 26-27. (in Russian).

Morris R.E. (1987). Factors, inducing the diapause of full Webworms. Canuct. Entomologist, 99, MS, 522-529. 
Morris R.F. \& Futtion W. (1970). Models for the development and survival of Hyphantria cunea in relation to temperature and humidit Entomol. Soc. Of Canada, 60.

Morris R.F. (1972). Fecundity and colony saize in natural populations of Hyphantria cunea. Cañad. Entomologist, 104, 3, $399-409$.

Movchan O.M. (2002). Karantinni shkidlivi organizmi. Chastina 1. Karantinni shkidniki. Kiyiv, Svit (in Ukrainian).

Nady B., Rcichart G. \& Ubrizsy G. (1953). Mierikai feher szovalepke (Hyphantria cunea Drury) Mugyarorzagon, Mexogazda sag, Kiado, Budapest, 120.

Nakonechna Yu.O. \& Stankevich S. V. (2019). Istoriya poshirennya ta suchasnij areal amerikanskogo bilogo metelika. Proceed. Sc. Conf. 19-20.03.2019. Harkiv, HNAU, 1, 136-138. (in Ukrainian).

Nordin C.Z., Rennels R.G. \& Maddox J.U. (1972). Parasites and Patogens of the fall wfebworm in Illinois. Environ Entomol, 1, 3, $352-359$.

Severin H.C. (1921). The tent-caterpillar and the fall webworm. breakings, S.D, 4.

Shestopalov M. \& Turin E. (2012). Amerikanskaya belaya babochka. Agrarnij tizhden, 24, 16. (in Russian).

Shumov S.N. (2018). O dinamike rasprostraneniya amerikanskoj beloj babochki Hyphantria cunea Drury., (Lepidoptera, Arctiidae,) v Ukraine na fone godovyh minimalnyh temperatur vozduha (s1952 g. i do nastoyashego vremeni). Ukrayinskij entomoloichnij zhurnal, 1 (14), 44-57. (in Ukrainian).

Sikura A.J. \& Dulo V.Yu. (1962). Zonalnoe i stacialnoe raspredelenie amerikanskij beloj babochki v Zakarpate. Vopr. Ekologii, 7, 164-165. (in Russian).

Sikura O.A. (2000). Zonalni osoblivosti rozpovsyudzhennya amerikanskogo bilogo metelika Hyphantria cunea Druru. (Lepidoptera: Arctiidae) v Zakarpatti. Izvestiya Harkovskogo entomologicheskogo obshestva, 2, 135-138. (in Ukrainian).

Stankevich S. V. \& Manukyan K. S. (2017). Amerikanskij bilij metelik na teritoriyi Maloroganskoyi silskoyi radi u 2014-2017 rr. Proceed. Int. Sc. Conf. "Naukovi zasadi pidvishennya efektivnosti silskogospodarskogo virobnictva", 23-24.10. 2017. Harkiv, HNAU, 312-313. (in Ukrainian).

Stankevich S. V. (2015). Amerikanskij bilij metelik (Hyphantria cunea) na teritoriyi Maloroganskoyi silskoyi radi. Ekologichni, ekonomichni ta socialni problemi rozvitku agrarnoyi sferi v umovah globalizaciy. Proceed. Int. Sc. Conf. 4-5.11.2015. Harkiv, HNAU, 1, 212-214. (in Ukrainian).

Stankevich S. V. (2016). Novij oseredok amerikanskogo bilogo metelika (Hyphantria cunea) u Harkivskomu rajoni. Proceed. Int. Sc. Conf. (7-9.11.2016. Kiyiv, Avalon-Print, 74-75. (in Ukrainian).

Stankevich S. V. (2016). Oseredok amerikanskogo bilogo metelika (Hyphantria cunea) u Harkivskomu rajoni. Proceed. IV Int. Sc. Conf. Uzhgorod, 15-17.09.2017. Ukrayinska entomofaunistika, 7 (3), 83-84. (in Ukrainian).

Stankevich S. V., Lezhenina I. P. \& Zabrodina I. V. (2017). Biologichni osoblivosti amerikanskogo bilogo metelika u Harkivskomu rajoni Harkivskoyi oblasti. Proceed. Int. Sc. Conf. 24-25.05.2017. Harkiv, HNAU, 179-180. (in Ukrainian).

Stankevich S. V., Lezhenina I.P. \& Zabrodina I. V. (2017). Morfologichni osoblivosti amerikanskogo bilogo metelika u Harkivskomu rajoni Harkivskoyi oblasti. Novitni agrotehnologiyi: teoriya ta praktika. Proceed. Int. Sc. Conf. Vinnicya, Nilan-LTD, 148-149. (in Ukrainian).

Stankevich S. V., Litvin S. \& Zorka O. (2016). Karantinni shkidlivi organizmi na teritoriyi Maloroganskoyi silskoyi radi Harkivskogo rajonu Harkivskoyi oblasti. Zahist roslin u HHI stolitti: Problemi ta perspektivi rozvitku. Proceed. Int. Sc. Conf. (22-23.09.2016). Harkiv, HNAU, 7678. (in Ukrainian).

Stankevich S. V., Nakonechna Yu.O. \& Manukyan K.S. (2018). Dinamika maloroganskogo oseredku amerikanskogo bilogo metelika (Hyphantria cunea (Drury, 1773) u 2014-2018 rr. Proceed. Int. Sc. Conf. 11-12.10.2018. Harkiv, HNAU, 114-116. (in Ukrainian).

Stankevich S.V. \& Nakonechna Yu.O. (2018). Suchasnij stan poshirennya regulovanih shkidlivih organizmiv na teritoriyi Harkivskoyi oblasti. Proceed. Int. Sc. Conf. 17-19.10.2018. Mikolayiv, MNAU, 73-74. (in Ukrainian).

Stankevich S.V., Beleckij E.N. \& Zabrodina I.V. (2019). Ciklicheski-nelinejnaya dinamika prirodnyh sistem i problemy prognozirovaniya. Vankuver, Accent Graphics Communications \& Publishing. Vankuver (in Russian).

Stankevych S. V., Yevtushenko M. D. \& Zabrodina I. V. (2019). V.V. Dokuchaiev Scientific School of Kharkiv National Agrarian University and development agricultural entomology in XIX-XXI centuries. Ukrainian Journal of Ecology, 9 (2), 156-169.

Stankevych S.V., Vasylieva Yu.V., Golovan L.V., Zabrodina I.V., Lutytska N.V., Nakonechna Yu.O., Molchanova O.A., Chupryna Yu.Yu., Zhukova L.V. (2019). Chronicle of insect pests massive reproduction. Ukrainian Journal of Ecology, 9 (1), 262-274.

Stankevych S. V. (2017). Fall webworm (Hyphantria cunea) in Kharkiv region. Znanstvena misel, 8 (8), 1, 10-14

Timchenko G.A. (1988). Spravochnik po zashite lesa ot vreditelej i boleznej. Kiyiv, Urozhaj (in Russian).

Tkalenko G. (2017). Biometod proti ABM. Agrobiznes sogodni, 22 (365), 23-26. (in Ukrainian).

Tokar O.P. \& Orlova O.M. (2014). Prognoz fitosanitarnogo stanu agrocenoziv Ukrayini ta rekomendaciyi shodo zahistu roslin u 2014 . Kiyiv, Granma (in Ukrainian).

Trigob'yuk M.I. (2005). Amerikanskij bilij metelik. Karantinnij organizm bagatorichnih nasadzhen ta zahodi obmezhennya jogo chiselnosti. Karantin i zahist roslin, 7, 13-16. (in Ukrainian).

Turenko V. P., Bilyk M. O. \& Zhukova L. V. (2019). Pathogens of spring barley on abiotic factors in the eastern forest - steppe of Ukraine. Ukrainian Journal of Ecology, 9 (2), 179-188.

Umnov M.P. (1955). Amerikanskaya belaya babochka (Hyphantria cunea Druru) - novyj v Evrope vreditel rastenij. Zoologiya, 6, $1292-1314$. (in Ukrainian).

Warren L.O. \& Tadic M. (1970). The fall webworm, Hyphantria cunea (Drury). Fayettaville: Agr. Exp. Sta. Univ. of Arkansas, $759,106$. Yasyukevich V.V. (2013). O formirovanii vtorichnogo areala amerikanskoj beloj babochki (Hyphantria cunea Drury, Arctiidae, Lepidoptera) v Rossii i sosednih stranah v XXI veke. Problemy ekologicheskogo monitoringa i kosistem. 25. Moscow. Institut of Global Climate and Ecology, 454-478. (in Russian).

Yemec O.M. \& Demenko V.M. (2014). Amerikanskij bilij metelik v umovah Ukrayini ta Pivnichno - Shidnogo Lisostepu. Agronomiya i biologiya, 9 (28), 22-25. (in Ukrainian).

Zapolovskij A.S. (2013). Amerikanskij bilij metelik - nebezpechnij karantinnij shkidnik. Zhitomir (in Ukrainian).

Zhukova L. V., Stankevych, S.V., Turenko, V.P. (2019). Root rots of spring barley, their harmfulness and the basic effective protection measures. Ukrainian Journal of Ecology, 9 (2), 232-238.

\section{Citation:}

Nakonechna, Yu.O., Stankevych, S.V., Zabrodina, I.V., Lezhenina, I.P., Filatov, M.O., Yushchuk, D.D., Lutytska, N.V., Molchanova, O.A., Melenti, V.O., Poliakh, V.M., Buhaiov, S.M., Belay, Yu.M., Martynenko, V.I., Zhukova, L.V., Buzina, I.M., Khainus, D.D. (2019). Distribution area of Hyphantria cunea Drury: the analysis of Ukrainian and world data. Ukrainian Journal of Ecology, 9(3), 214-220.

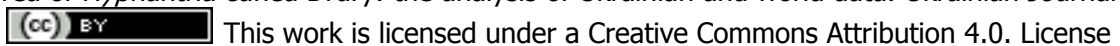

